\title{
Humoral response to wheat protein in patients with coeliac disease and enteropathy associated $T$ cell lymphoma
}

\author{
CLIONA O'FARRELLY, C FEIGHERY, D S O'BRIAIN, F STEVENS, C E CONNOLLY, \\ C MCCARTHY, D G WEIR
}

\begin{abstract}
Features that might distinguish uncomplicated coeliac disease from enteropathy associated $T$ cell lymphoma were investigated. Of 76 patients with coeliac disease, $71(93 \%)$ had raised levels of $\alpha$ gliadin antibody and all responded clinically and histologically to treatment with a gluten free diet. In contrast, none of 16 patients with enteropathy associated $T$ cell lymphoma had raised levels of $\alpha$ gliadin antibody, and treatment with a gluten free diet resulted in histological improvement in one and transient clinical improvement in six patients. The ratio of women to men was $2 \cdot 2: 1$ in the group with coeliac disease and 1:1.6 in the patients with enteropathy associated $T$ cell lymphoma.

Thus patients with enteropathy associated $T$ cell lymphoma do not display a humoral immune response to wheat protein $(\alpha$ gliadin), rarely respond to a gluten free diet, and are often men. Patients with uncomplicated coeliac disease usually have raised levels of $\alpha$ gliadin antibody, always respond to a gluten free diet, and are frequently women. These findings suggest the presence of two separate forms of enteropathy: one is benign and sensitive to wheat protein whereas the other runs a malignant course.
\end{abstract}

\section{Introduction}

Coeliac disease is characterised by an enteropathy sensitive to gluten that produces symptoms because of malabsorption of food. ${ }^{1}$ Withdrawal of wheat protein from the diet usually results in a clinical improvement that correlates with histological reversal of the enteropathy. ${ }^{2}$ Malignant lymphomas may present with malabsorption and a jejunal mucosal lesion similar to that found in coeliac patients. ${ }^{3}$ Lymphoma associated with enteropathy was formerly called malignant histiocytosis of the intestine, but it now seems that the malignant cell in these lymphomas is usually of $\mathrm{T}$ cell origin..$^{46}$ In this study intestinal lymphoma associated with abnormal jejunal histology is called enteropathy associated $\mathrm{T}$ cell lymphoma.

Well controlled coeliac disease has an excellent prognosis, whereas intestinal lymphomas carry a high mortality. ${ }^{7}$ Early resection of a localised malignant lesion is thought to improve survival, ${ }^{8}$ but because of the similarity in presentation of coeliac disease and enteropathy associated $T$ cell lymphoma accurate diagnosis is frequently delayed. The common clinical problem is whether a

\footnotetext{
Departments of Clinical Medicine, Immunology, and Histopathology, Trinity College, and St James's Hospital, Dublin

CLIONA O'FARRELLY, PHD, research fellow in immunology

C FEIGHERY, MD, FRCPI, senior lecturer in immunology

D S O'BRIAIN, MB, MRCPATH, consultant histopathologist

D G WEIR, MD, FRCPI, regius professor of physic
}

Departments of Medicine and Histopathology, University College, and Regional Hospital, Galway

F STEVENS, MB, MRCPI, lecturer in medicine

C E CONNOLLY, FRCPG, FCAP, consultant histopathologist

C MCCARTHY, MD, FRCPI, professor of medicine

Correspondence to: Professor Weir. patient with villous atrophy of the small intestine is suffering from enteropathy associated T cell lymphoma or coeliac disease. Any detectable difference in the immunological manifestations of the two conditions would facilitate this distinction.

An abnormal immunological response to wheat protein is a feature of coeliac disease, as both cellular ${ }^{9}$ and humoral ${ }^{10}$ sensitisation to $\alpha$ gliadin, a purified wheat protein, are known to be specific for the disorder. We compared $\alpha$ gliadin antibody levels in patients with coeliac disease with no complications and in patients with enteropathy associated $\mathrm{T}$ cell lymphoma.

\section{Patients and methods}

Two hundred and fifty patients being investigated for malabsorption were assessed clinically and had duodenal-jejunal biopsy specimens taken and serum $\alpha$ gliadin antibody levels measured. We also measured $\alpha$ gliadin antibody levels in seven patients who presented with perforation or intestinal obstruction and were diagnosed as having enteropathy associated $\mathrm{T}$ cell

Clinical details of 16 patients with enteropathy associated T cell lymphoma

\begin{tabular}{|c|c|c|c|c|c|c|}
\hline \multirow{2}{*}{$\begin{array}{l}\text { Case } \\
\text { No }\end{array}$} & \multirow[b]{2}{*}{ Sex } & \multirow{2}{*}{$\begin{array}{c}\text { Age at } \\
\text { diagnosis } \\
\text { of EATL* }\end{array}$} & \multirow{2}{*}{$\begin{array}{c}\text { Duration } \\
\text { of } \\
\text { symptoms }\end{array}$} & \multicolumn{2}{|c|}{ Response to gluten free diet } & \multirow{2}{*}{$\begin{array}{c}\text { Presence } \\
\text { of } \\
\text { HLA-DR3 }\end{array}$} \\
\hline & & & & Clinical & Histological & \\
\hline 1 & M & 67 & $3 / 12$ & - & - & \\
\hline 2 & $\mathrm{~F}$ & 36 & Since childhood & + & - & \\
\hline 3 & $M$ & 40 & $7 / 12$ & + & + & \\
\hline 4 & $\mathrm{~F}$ & 62 & $30 \mathrm{yrs}$ & + & - & + \\
\hline 5 & $\mathrm{~F}$ & 74 & $9 / 12$ & + & - & - \\
\hline 6 & $M$ & 73 & $2 \mathrm{yrs}$ & - & - & \\
\hline 7 & M & 39 & $3 / 12$ & \multicolumn{2}{|r|}{ No diet } & \\
\hline 8 & $\mathrm{~F}$ & 63 & Since childhood & - & Noce & \\
\hline 9 & $\mathrm{~F}$ & 74 & 3 yrs & - & - & \\
\hline 10 & $M$ & 37 & $7 / 12$ & + & - & \\
\hline 11 & M & 63 & $3 \mathrm{yrs}$ & + & & \\
\hline 12 & $M$ & 58 & $3 / 12$ & \multicolumn{2}{|r|}{ No diet } & - \\
\hline 13 & $\mathrm{~F}$ & 64 & $3 \mathrm{yrs}$ & - & - & \\
\hline 14 & $\mathrm{~F}$ & 70 & Since childhood & \multirow{2}{*}{\multicolumn{2}{|c|}{ No diet }} & + \\
\hline 15 & M & 39 & 5 yrs & & & \\
\hline 16 & M & 40 & $3 / 12$ & \multicolumn{2}{|r|}{ No diet } & - \\
\hline
\end{tabular}

^EATL $=$ Enteropathy associated human $\mathrm{T}$ cell lymphoma.

lymphoma and in four patients with confirmed coeliac disease and a malignancy other than enteropathy associated $T$ cell lymphoma (one adenocarcinoma of the jejunum; one colorectal carcinoma; one carcinoma of the stomach; and one B cell lymphoma).

Of the 250 patients with malabsorption, 76 had classical coeliac disease, ${ }^{1}$ having villous atrophy which responded clinically and histologically to treatment with a diet free of gluten. Enteropathy associated $T$ cell lymphoma was diagnosed in 16 patients. The histological typing of the lymphoma was as described by Isaacson and Wright. ${ }^{3}$

Levels of $\alpha$ gliadin antibody were determined using the enzyme linked immunosorbent assay as described previously. ${ }^{10} \mathrm{An}$ index of greater than the mean of a normal control group plus two standard deviations was considered to be positive. Levels of antibody to $\beta$ lactoglobulin were measured using the same technique. Concentrations of IgG, IgA, and IgM were measured in the patients with malignancy using laser nephelometry. ${ }^{11}$ HLA-DR typing was carried out on purified B cells from five of the patients with enteropathy associated $T$ cell lymphoma and 61 coeliac patients. The antisera were obtained from the National Institutes of Health, Bethesda, and the technique of Terasaki $e t$ al was used. ${ }^{12}$ 


\section{Results}

\section{$\alpha$ GLIADIN ANTIBODIES AND MALABSORPTION}

Two hundred and fifty patients were investigated for malabsorption. Normal levels of $\alpha$ gliadin antibodies were found in 90 of 105 patients (85\%) with normal small intestinal mucosa. These patients did not undergo further investigation. Of 145 patients with villous atrophy (table), 120 had raised $\alpha$ gliadin antibody levels. The results of repeat biopsies after treatment with a gluten free diet were available for 85 of these 120 patients. Of the 85,71 $(83 \%)$ responded clinically and histologically to this diet. Levels of $\alpha$ gliadin antibody decreased in the patients whose histology improved but remained associated $\mathrm{T}$ cell lymphoma had raised $\alpha$ gliadin antibody levels. Hypogammaglobulinaemia was not shown in any case, but raised levels of antibody to $\beta$ lactoglobulin, another dietary protein, were detectable in eight of 12 patients tested.

Villous atrophy was found in all 16 patients with enteropathy associated $T$ cell lymphoma. Lymphoma affected the small intestine in 14 of these cases, and disease of the mesenteric nodes without identifiable intestinal lymphoma occurred in the remaining two patients. Twelve patients were treated with gluten free diet, and 10 of these underwent a second biopsy, only one patient showing a histological response. A transient clinical response was observed in six of 12 patients.

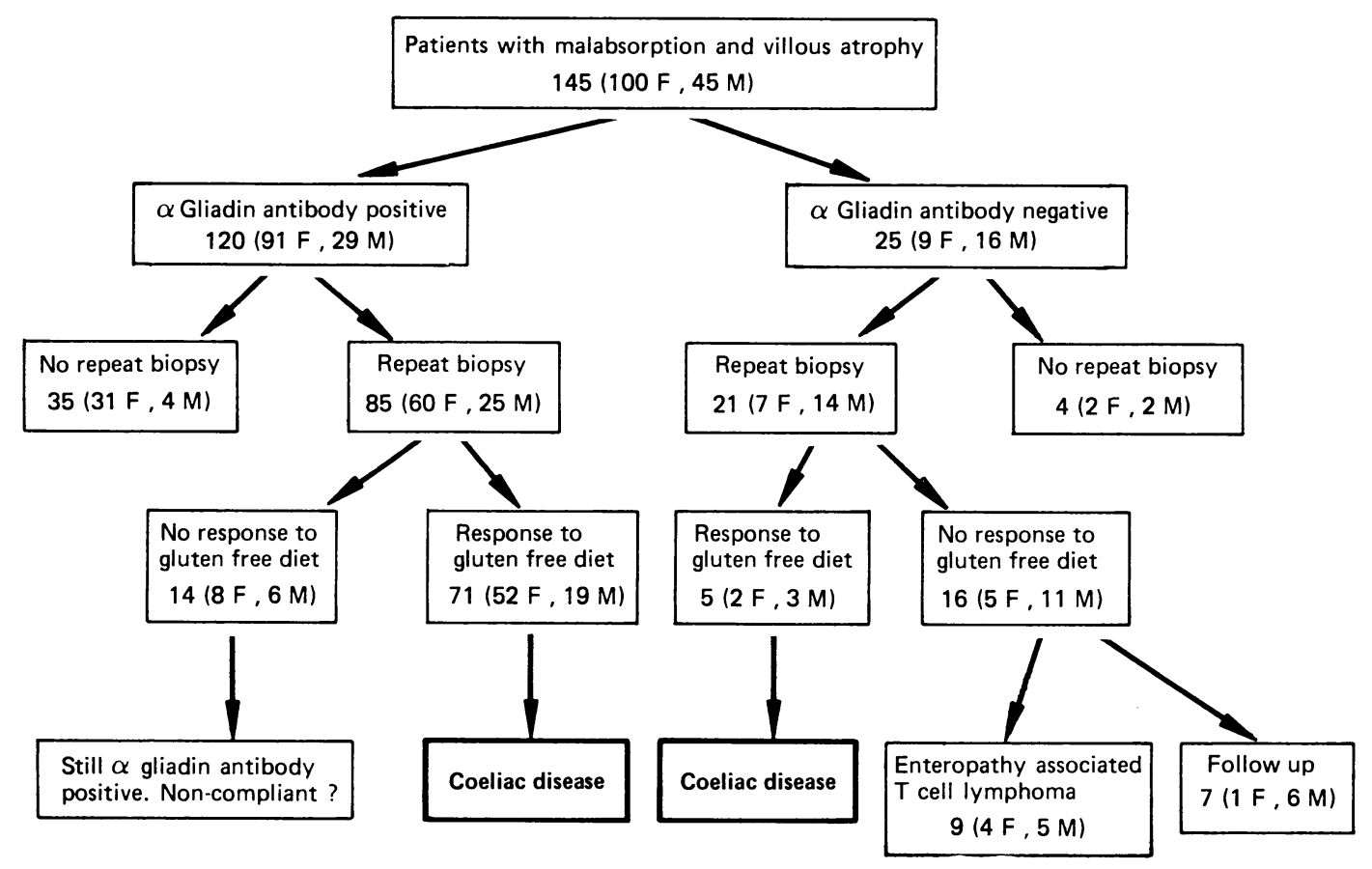

Distribution of patients with malabsorption and villous atrophy with regard to $\alpha$ gliadin antibody state, sex, response to gluten free diet, and diagnosis.

unchanged in the 14 patients who did not respond, suggesting that these patients were not adhering strictly to the diet.

Levels of the antibody were normal in 25 of the 145 patients with villous atrophy, and biopsies were repeated in 21 after gluten had been withdrawn. In five of the 21 patients $(24 \%)$ the clinical and histological response to the gluten free diet enabled a diagnosis of coeliac disease to be established. Of the remaining 16 patients, seven did not respond to treatment with diet and were followed up; enteropathy associated $\mathrm{T}$ cell lymphoma was diagnosed in the remaining nine.

\section{$\alpha$ GLIADIN ANTIBODIES AND COELIAC DISEASE}

Of the 106 patients in the table for whom follow up information was available, 76 responded histologically and clinically to the gluten free diet and were diagnosed as having coeliac disease. Of these, $71(93 \%)$ had raised $\alpha$ gliadin antibody levels.

Raised levels of $\alpha$ gliadin antibody were also detected in three of the four patients with confirmed coeliac disease and malignancy other than enteropathy associated $T$ cell lymphoma. The patients with adenocarcinoma of the jejunum, colorectal carcinoma, and B cell lymphoma had raised levels while the patient with cancer of the stomach had normal levels.

\section{$\alpha$ GLIADIN ANTIBODIES AND ENTEROPATHY ASSOCIATED T CELL LYMPHOMA}

In all, 16 patients with enteropathy associated $T$ cell lymphoma were studied (figure). Of these, nine were among the 250 patients who presented with malabsorption and seven were patients who presented with perforation or intestinal obstruction. None of the 16 patients with enteropathy

\section{HLA-DR TYPING}

HLA-DR3 was expressed in 55 of 61 coeliac patients (90\%) and two of five patients $(40 \%)$ with enteropathy associated T cell lymphoma who were DR typed.

\section{SEX RATIOS}

The ratio of women to men in the total group with villous atrophy and malabsorption (145) was $2: 1$. This ratio was increased in those with malabsorption and villous atrophy who were positive for $\alpha$ gliadin antibody $(3 \cdot 1: 1)$ but was reversed both in the group of those who were negative for $\alpha$ gliadin antibody $(1: 1 \cdot 7)$ and in the group with enteropathy associated $T$ cell lymphoma $(1: 1 \cdot 6)$. In the 76 patients with uncomplicated coeliac disease the ratio of women to men was $2 \cdot 2: 1$.

\section{Discussion}

The diagnosis of enteropathy associated $\mathrm{T}$ cell lymphoma may be difficult, whether it occurs as a complication of coeliac disease or alone. The presenting symptoms and the histological lesion of the small intestine in patients with enteropathy associated $T$ cell lymphoma and coeliac disease are similar and difficult to distinguish clinically or histologically. This study shows that most true coeliac patients have increased concentrations of antibody to $\alpha$ gliadin which return to normal if the patient follows a gluten free diet and responds both clinically and histologically. Patients with enteropathy associated $\mathrm{T}$ cell lymphoma do not have $\alpha$ gliadin antibodies 
and at best respond only transiently to the conventional treatment for coeliac disease.

The total immunoglobulin concentrations were normal in all 16 patients with enteropathy associated $T$ cell lymphoma, and raised levels of antibodies to $\beta$ lactoglobulin, a second dietary protein, were detectable in eight of 12 tested. These results show that the humoral immune system of patients with enteropathy associated $\mathrm{T}$ cell lymphoma is intact and capable of responding to the excess antigenic challenge resulting from the damaged mucosa. The raised levels of $\alpha$ gliadin antibody in three coeliac patients with small intestinal adenocarcinoma, colorectal carcinoma, and B cell lymphoma, respectively, indicate that malignancy itself is not responsible for low levels of $\alpha$ gliadin antibody. The specific absence of a humoral response to $\alpha$ gliadin is remarkable and suggests that the antigen may play a part in the pathogenesis of enteropathy associated $\mathrm{T}$ cell lymphoma.

The malignant cell in enteropathy associated $\mathrm{T}$ cell lymphoma has recently been shown to be of $\mathrm{T}$ cell origin. ${ }^{46}$ We have previously shown that $\alpha$ gliadin activates suppressor cells in some coeliac patients and have suggested that this is a $\mathrm{T}$ cell phenomenon. ${ }^{13}$ This cell could either have been affected by the malignant process or have become malignant itself in patients with enteropathy associated $\mathrm{T}$ cell lymphoma, causing a specific absence of a humoral response to $\alpha$ gliadin. Alternatively, it is possible, as we have previously suggested, ${ }^{14}$ that the case in patients with enteropathy associated $\mathrm{T}$ cell lymphoma is similar to that found in patients with mycosis fungoides. A clone of malignant T cells developing in the intestine over a period of years could produce an enteropathy resembling coeliac disease which was not sensitive to wheat protein. Infection with an HTLV type retrovirus, as has been implicated in mycosis fungoides, ${ }^{16}$ may be important in initiating the malignant process. The transient response to a gluten free diet seen in some patients may simply be due to the removal of a particularly antigenic dietary protein from an already chronically inflamed intestine. ${ }^{\text {to }}$

Two studies have shown that the DR3 antigen is associated with both uncomplicated coeliac disease and coeliac disease with malignancy. ${ }^{718}$ This antigen is common in the Irish population, and its frequency may relate to the high incidence of coeliac disease seen in Ireland. ${ }^{19}$ " Functional abnormalities of the immune response that are associated with the DR3 antigen are thought to predispose this population to autoimmune disorders and coeliac disease." In our study the DR3 antigen was found in 55 of 61 coeliac patients $(90 \%)$ but in only two of five patients with enteropathy associated T cell lymphoma who were tested.

It is well known that coeliac disease is more common in women."2 Sex hormones are known to play a part in the regulation of the immune response $\mathrm{e}^{23}$ and may contribute to the increased incidence of autoimmune disease seen among women. ${ }^{24}$ The ratio of women to men in this Irish population of coeliac patients was $2 \cdot 2: 1$, which is high. Women with coeliac disease are also more likely to have raised levels of $\alpha$ gliadin antibodies, the ratio of women to men in the group positive for $\alpha$ gliadin antibodies being $3 \cdot 1: 1$. This ratio is reversed in both the group negative for $\alpha$ gliadin antibodies $(1: 1 \cdot 7)$ and the group with enteropathy associated $\mathrm{T}$ cell lymphoma $(1: 1 \cdot 6)$. These findings suggest that raised levels of $\alpha$ gliadin antibodies, common among women with coeliac disease, indicate that the disease is benign. A small proportion of patients with uncomplicated coeliac disease have normal levels of $\alpha$ gliadin antibody, indicating that enhanced humoral sensitisation to wheat protein is not of primary pathogenic importance. The finding in the coeliac population, however, of a subgroup of patients who are predominantly men, respond poorly to gluten withdrawal, and are negative for $\alpha$ gliadin antibodies suggests that this group is most at risk of developing the gluten resistant enteropathy associated $\mathrm{T}$ cell lymphoma.

In conclusion, this study indicates differences between uncomplicated coeliac disease and enteropathy associated $\mathrm{T}$ cell lymphoma with respect to $\alpha$ gliadin antibody state, gluten response, and incidence in men and women. Predictive characteristics of enteropathy associated $\mathrm{T}$ cell lymphoma include being male, a minimal response to a gluten free diet, and absence of $\alpha$ gliadin antibodies. In patients with coeliac disease sex and DR state may affect the incidence of development of lymphomas, which may independently interfere with production of $\alpha$ gliadin antibodies. Alternatively, an initially slowly progressive $\mathrm{T}$ cell intestinal lymphoma may occur, which is analogous to mycosis fungoides and mimics coeliac disease.

We thank the American Irish Foundation for financial support; $\mathrm{Mr} \mathrm{T}$ Finch, the National Blood Transfusion Service, Dublin; and Ms M Bourke, department of medicine, Galway Regional Hospital, for HLA DR typing. We also thank Dr Peter Daly, Dr J Atherton, Dr N Keeling, and Professor T Hennessy for allowing us to study their patients and Dr Dermot Kelleher for helpful discussion.

\section{References}

1 Cooke WT, Asquith P. Introduction and definition of coeliac disease. Clin Gastroenterol 1974;3 $3-10$

2 Stewart J. Clinical and morphologic response to gluten withdrawal. Clin Gastroenterol 1974;3 109-26

3 Isaacson P. Wright DH. Intestinal lymphoma associated with malabsorption. Lancet 1978; $67-70$

4 Isaacson PG, Spencer J, Connolly CE, et al. Malignant histiocytosis of the intestine: a T-cell lymphoma. Lancet 1985;ii:688-91.

Loughran TP, Kadin ME, Deeg HJ. T-cell intestinal lymphoma associated with celiac sprue. Ann Intern Med 1986;104:44-7.

6 Salter DM. Krajewski AS, Dewar AE. Immunophenotype analysis of malignant histiocytosis of the intestine. F Clin Pathol 1986;39:8-15

Bouchier IA. Intestinal tumours. In: Bouchier IA, ed. Gastroenterologv. 3rd ed. London: Baillière Tindall, 1982:149.

8 Swinson CM, Coles EC, Slavin G, Booth CC. Coeliac disease and malignancy. Lancet 1983; $111-5$.
owinson

9 O'Farrelly C, Feighery C, Greally J, Weir DG. Cellular response to alpha gliadin in untreated coeliac disease. Gut 1982:23:83-7.

10 O'Farrelly C, Kelly J. Hekkens W', et al. Alpha gliadin antibody levels: a serological test for coeliac disease. Br.Med f 1983;286:2007-10

11 Daigneault R, Lemieux D. Evaluation of a Behring laser nephalometer prototype in the measurement of $\mathrm{IgG}$, IgA and IgM. Clin Biochem 1978;11:28-31.

12 Terasaki PI, Bernoco D, Park MS, Ozturk G, Iwaki Y. Microdroplet testing for HLA A, B, Cand Dr antigens. Am $\mathcal{F}$ Clin I'athol 1978;69:103-20.

13 O'Farrelly C, Feighery CF, Whelan CA, Weir DG. Suppressor cell activity in coeliac disease induced by alpha gliadin, a dietary antigen. Lancet 1984 ;ii: 1305-7.

14 Hourihane DO'B, W'eir DG. Malignant celiac syndrome. Gastroenterologv 1970;29:130-9.

15 Slater DN. Rooney N, Bleenan S, Hamed A. The lymph node in mvcosis fungoides: a light and electron microscopy and immunohistologicai study supporting the Langerhan's cell retrovirus hypothesis. Histopathologv 1985;9:587-621.

16 Kieffer M, Frazier PJ, Daniels NWR, Coombs RRA. Wheat gliadin fractions and other cereal antigens reactive with antibodies in the sera of coeliac patients. Clin Exp Immunol 1982;50. $651-60$

17 O'Driscoll BRC, Stevens FM, O'Gorman TA, et al. HLA type of patients with coeliac disease and malignancy in the west of Ireland. Gut 1982;23:662-5.

18 Swinson CM, Hall PJ, Bedford PA, Booth CC HLA antigens in cocliac disease associated with malignancy. Gut 1983:24:925-8.

19 McKenna R, Stevens FM, Bourke M, McNicholl B, Albert ED, McCarthy CF. B-cell alloantigens associated with coeliac disease. In: McConnell RB, ed. Genetics of coeliac disease. Lancaster: MTP Press, 1981:153-8.

20 Mylotte M, Egan-Mitchell B. McCarthy CF, McNicholl B. Incidence of coeliac disease in the west of Ireland. BrMed F 1973:i:703-5.

21 Schwarty. BD, Shreffler DC. Genetic influences on the immune response. In: Parker CW, ed. Clinical immunology. Philadelphia: WB Saunders, 1980:49-85.

22 Cooke WT, Holmes GKT. Definition and epidemiology. In: Cooke WT, Holmes GKT, eds. Coeliac Disease. London: Churchill Livingstone, 1984:11-22.

23 Ansar Ahmed S, Penhale $W_{J}$, Talal $\mathbf{N}$. Sex hormones, immune responses and autoimmune diseases. Am 7 Pathol 1985;121:531-51.

24 Wolstenholme GEW', Knight J. Hormones and the immune response. Ciba foundation study group No 36. London: Churchill Press, 1970.

(Accepted 8 July 1986

\section{YEARS AGO}

A matron-teterrima causa belli-is once more the cause of the resignation, en masse, of the medical staff of a hospital. The circumstances are complicated by unimportant side-issues, which are always imported into such a dispute by hospital committees when they have "committed" themselves to the strong partisanship of an individual whose flag they have hoisted. The conduct of the committee appears to be insufficiently regardful of the gravity of the trust confided to them for the relief of the sick and the medical treatment of the poor. Their justification, as described by themselves, is feeble in the extreme; and wisdom and public spirit will probably lead them in the end-and we hope it will come before long-to learn that an honorary medical staff must be trusted to have the power of judgment as to the suitability of any one of the subordinate officers; and that to accept the resignation of a whole medical staff rather than give up the services of a favourite matron, is to sacrifice the steering of a ship to a fancy for its head steward, with whom the sailing officers decline to work on grounds alleged. It is, from this point of view, a failure of public duty. (British Medicalfournal 1886 ;ii:261.) 